\title{
PERKEMBANGAN DAN PERMASALAHAN HAK KESETARAAN DALAM PELAYANAN KESEHATAN DI MASYARAKAT
}

\author{
Triana Devi Fatimah \\ Institut Ilmu Kesehatan Strada Indonesia \\ 25triadevi062003@gmail.com
}

\begin{abstract}
Abstrak
Pelayanan kesehatan merupakan hal yang sangat penting dalam kehidupan masyarakat, dan merupakan hak masyarakat dalam mendapatkan pelayanan kesehatan yang baik. Negara mempunyai kewajiban dalam memenuhi kebutuhan masyarakat terhadap pelayanan kesehatan yang diatur dalam Undang-Undang Dasar Negara Republik Indonesia tahun 1945, serta Peraturan Perundang-Undangan yang mendukung yaitu Undang-Undang Nomor 25 tentang Pelayanan Publik, UndangUndang Nomor 36 tahun 2009 tentang kesehatan, Undang-Undang Nomor 44 tahun 2009 Tentang Rumah Sakit, dan Undang-Undang 37 Tahun 2008 tentang Ombudsman Republik Indonesia. Dalam penyelenggraannya, pelayanan kesehatan yang merupakan bagian dari pelayanan publik tidak berjalan mulus. Terdapat keluhan-keluhan yang dirasakan oleh masyarakat mengenai pelayanan yang diberikan oleh rumah sakit sebagai instansi penyelenggara.

Undang-Undang Dasar Negara Republik Indonesia Tahun 1945 menjamin hak untuk mendapatkan lingkungan hidup yang baik, sehat serta berhak memperoleh pelayanan kesehatan. Negara memiliki peran dalam melakukan upaya kesehatan yang tersusun. Negara memiliki peran dalam melakukan upaya kesehatan secara tersusun, menyeluruh dan merata yang penting artinya bagi pembentukan sumber daya manusia Indonesia, peningkatan ketahanan, daya saing bangsa, serta ketahanan nasional. Dalam menciptakan perkembangan kesehatan untuk kesejahteraan, maka diperlukan tenaga kesehatan yaitu setiap orang yang mengabadikan diri dalam bidang kesehatan serta memiliki pengetahuan atau memiliki keterampilan melalui pendidikan dibilang kesehatan untuk jenis tertentu memerlukan kewenangan untuk melakukan upaya kesehatan. Dokter merupakan tenaga kesehatan sebagaimana diatur dalam Pasal 2 ayat (2) sampai dengan ayat (8) Peraturan Pemerintah Nomor 32 Tahun 1996 tentang Tenaga Kesehatan.
\end{abstract}

\section{Latar Belakang}

Hak atas kesehatan bersifat mutlak dan erat kaitannya dengan kesejahteraan masyarakat. Undang-Undang Dasar Negara Republik Indonesia Tahun 1945 menjamin hak untuk mendapatkan lingkungan hidup yang baik, sehat serta berhak memperoleh pelayanan kesehatan. Negara memiliki peran dalam melakukan upaya kesehatan yang tersusun. Negara memiliki peran dalam melakukan upaya kesehatan secara tersusun, menyeluruh dan merata yang penting artinya bagi pembentukan sumber daya manusia Indonesia, peningkatan ketahanan, daya saing bangsa, serta ketahanan nasional. Dalam menciptakan perkembangan kesehatan untuk kesejahteraan, maka diperlukan tenaga kesehatan yaitu setiap orang yang 
mengabadikan diri dalam bidang kesehatan serta memiliki pengetahuan atau memiliki keterampilan melalui pendidikan dibilang kesehatan untuk jenis tertentu memerlukan kewenangan untuk melakukan upaya kesehatan. Dokter merupakan tenaga kesehatan sebagaimana diatur dalam Pasal 2 ayat (2) sampai dengan ayat (8) Peraturan Pemerintah Nomor 32 Tahun 1996 tentang Tenaga Kesehatan.

Dalam forum internasional berulang kali menegaskan bahwa setiap bangsa berhak menentukan nasibnya sendiri. Hak berkaitan erat dengan posisi manusia dengan sebagai subyek hukum. Tapi, disamping itu hak berhubungan erat dengan manusia sebagai makluk moral begitu saja dan karena itu perlu dipelajari juga dalam rangka etika umum. Oleh sebab itu penyusun membuat artikel ini agar dapat dimanfaatkan oleh para pembaca.

\section{Kasus/Masalah}

Bagaimana perkembangan dan permasalahan hak kesetaraan dalam pelayanan kesehatan di masyarakat?

\section{Tinjauan Pustaka}

Hak atas kesehatan saling tergantung, terkait, dan berhubungan dengan hak asasi lainnya. Bila hak atas kesehatan tidak terwujud maka akan terhambat terpenuhinya hak-hak lainnya seperti hak untuk hidup, hak atas pendidikan, hak atas pekerjaan, maupun hak untuk berserikat, berkumpul, dan menyatakan pendapat. Sedangkan pelanggaran terhadap hak asasi lainnya dapat berdampak pula terhadap perwujudan hak atas kesehatan. Manakala terjadi pelanggaran terhadap hak untuk bebas dari penyiksaan, hak untuk kondisi kerja yang baik, hak mendapatkan perumahan, makanan, dan jaminan sosial dapat berakibat tidak terwujudnya hak mendapatkan derajat kesehatan yang setinggi-tingginya.

\section{Kesehatan Sebagai Hak Asasi Manusia dilindungi secara Global}

Kesehatan sebagai hak asasi manusia dinyatakan pada Konstitusi WHO (World Health Organization) yang ditetapkan pada tahun 1946. Pada alinea ke 2 mukadimah Konstitusi WHO disebutkan bahwa, mendapatkan derajat kesehatan yang setinggitingginya merupakan hak fundamental setiap orang, tanpa membedakan ras, agama, gender, pandangan politik, dan kondisi ekonomi atau sosial.

Deklarasi Universal Hak Asasi Manusia yang disahkan pada sidang PBB 10 desember 1948 mencantumkan pula kesehatan sebagai hak asasi manusia. Deklarasi tersebut merupakan tonggak sejarah terpenting dalam penegakan hak asasi manusia, dan 10 Desember yang merupakan tanggal pengesahannya kini setiap tahun di seluruh dunia diperingati sebagai Hari Hak Asasi Manusia. Pasal 25 ayat (1) deklarasi tersebut menyatakan bahwa, setiap orang memiliki hak untuk hidup sehat yang layak bagi dirinya sendiri dan keluarganya, dalam pengertian yang luas termasuk hak atas makanan, pakaian, pelayanan kesehatan, dan pelayanan sosial yang diperlukan. 
Berdasarkan Deklarasi Universal Hak Asasi Manusia, terdapat 2 kelompok besar hak asasi manusia yaitu yang menyangkut hak sipil serta politik (sispol) dan yang menyangkut hak ekonomi, sosial serta budaya (ekosob). Mengenai hak asasi manusia di bidang ekosob selanjutnya pada sidang PBB di tahun 1966 ditetapkan Kovenan Internasional Tentang Hak-Hak Ekonomi, Sosial dan Budaya. Pada pasal 12 kovenan tersebut dinyatakan mengenai hak setiap orang untuk mendapatkan standar kesehatan fisik dan mental yang setinggi-tingginya. Kemudian untuk mewujudkannya terutama perlu dipenuhinya:

1. Hak kesehatan ibu dan anak serta kesehatan reproduksi

2. Hak atas lingkungan hidup dan lingkungan kerja yang sehat

3. Hak atas pencegahan, perawatan, dan pengendalian penyakit

4. Hak untuk mendapatkan fasilitas, peralatan, obat, dan pelayanan kesehatan

Elaborasi kesehatan sebagai hak asasi manusia dilakukan oleh Committee on Economic, Social and Cultural Rights (CESCR) yang merupakan komite di bawah PBB dan WHO. Menurut CESCR terdapat 4 komponen utama kesehatan sebagai hak asasi manusia yaitu:

- Ketersediaan (Availability)

Cukup tersedianya fasilitas, peralatan, obat, serta pelayanan kesehatan, termasuk tenaga kesehatan.

- Keterjangkauan (Accessibility)

Setiap orang dapat memperoleh pelayanan kesehatan, dengan cakupan dimensinya:

1. Nondiskriminasi: setiap orang dapat menjangkau pelayanan kesehatan tanpa diskriminasi terutama bagi kelompok masyarakat rentan dan terpinggirkan. Tidak boleh ada diskriminasi untuk mendapatkan pelayanan kesehatan berdasarkan gender, ras, warna kulit, bahasa, agama, pandangan politik, status kesehatan dan latar belakang sosial

2. Keterjangkauan fisik: sarana dan pra sarana kesehatan secara fisik harus bisa dijangkau secara aman oleh semua orang

3. Keterjangkauan ekonomi: setiap orang dapat menjangkau pelayanan kesehatan tanpa pembatasan ekonomi, terutama bagi masyarakat miskin

4. Keterjangkauan informasi: setiap orang dapat menjangkau informasi mengenai kesehatan, hak dan kewajiban pasien, serta hal-hal lainnya terkait dengan hak atas kesehatan. Setiap orang berhak mencari, menerima dan memberitahukan informasi mengenai kesehatan 
- $\quad$ Penerimaan (Acceptability)

Pelayanan kesehatan agar dapat diterima harus sesuai dengan etika kedokteran dan budaya masyarakat, serta menghargai pasien dan menjaga rahasia kedokteran.

\section{$\underline{\text { Kualitas (Quality) }}$}

Setiap orang harus mendapatkan pelayanan kesehatan dengan kualitas yang baik sesuai dengan kaidah ilmiah dan ilmu kedokteran.

\section{Hukum Kesehatan Sebagai Hak Asasi Manusia}

Kesehatan sebagai hak asasi manusia terdapat pada Undang-Undang Dasar 1945 (UUD 1945). Amandemen UUD 1945 menambahkan hak asasi manusia secara lebih lengkap dan rinci, antara lain berisikan mengenai kesehatan sebagai hak asasi manusia. Pasal 28H ayat (1) UUD 1945 menyatakan bahwa, setiap orang berhak hidup sejahtera lahir dan batin, bertempat tinggal, dan mendapatkan lingkungan hidup yang baik dan sehat serta berhak memperoleh pelayanan kesehatan. Pelaksanaannya ditetapkan pada pasal 34 ayat (3) UUD 1945 yakni, negara bertanggung jawab atas penyediaan fasilitas pelayanan kesehatan dan fasilitas pelayanan umum yang layak.

Ketentuan pada UUD 1945 tersebut kemudian dijabarkan menjadi pengaturan lebih lanjut dalam Undang-Undang Kesehatan yaitu UU no 36 tahun 2009. Pada UndangUndang Kesehatan dikemukakan bahwa, kesehatan merupakan hak asasi manusia dan salah satu unsur kesejahteraan yang harus diwujudkan sesuai dengan cita-cita bangsa Indonesia sebagaimana dimaksud dalam Pancasila dan UUD 1945. Pada UndangUndang Kesehatan tersebut juga dinyatakan bahwa, semua orang berhak atas kesehatan yakni hak untuk memperoleh pelayanan kesehatan dari fasilitas pelayanan kesehatan agar dapat mewujudkan derajat kesehatan yang setinggi-tingginya.

Selanjutnya pada Undang-Undang Kesehatan disebutkan mengenai hak atas kesehatan mencakup:

Setiap orang mempunyai hak yang sama dalam memperoleh akses atas sumber daya di bidang kesehatan

Setiap orang mempunyai hak dalam memperoleh pelayanan kesehatan yang aman, bermutu, dan terjangkau

Setiap orang berhak secara mandiri dan bertanggung jawab menentukan sendiri pelayanan kesehatan yang diperlukan bagi dirinya

Setiap orang berhak mendapatkan lingkungan yang sehat bagi pencapaian derajat kesehatan

Setiap orang berhak untuk mendapatkan informasi dan edukasi tentang kesehatan yang seimbang dan bertanggung jawab 
Setiap orang berhak memperoleh informasi tentang data kesehatan dirinya termasuk tindakan dan pengobatan yang telah maupun yang akan diterimanya dari tenaga kesehatan.

Pada Undang-Undang no 39 tahun 1999 tentang Hak Asasi Manusia ditetapkan bahwa setiap orang berhak atas lingkungan hidup yang baik dan sehat. Sedangkan Kovenan Internasional Tentang Hak-hak Ekonomi, Sosial dan Budaya, yang didalamnya menetapkan kesehatan sebagai hak asasi manusia juga telah diratifikasi menjadi Undang-Undang no 11 tahun 2005.

\section{Permasalahan}

Permasalahan kesehatan sebagai hak asasi manusia terutama mengenai belum terpenuhinya hak atas kesehatan serta terjadinya pelanggaran terhadap hak asasi di bidang kesehatan. Belum terpenuhinya hak atas kesehatan dengan masih terdapatnya disparitas kesehatan. Sedang pelanggaran terhadap hak asasi di bidang kesehatan terutama dalam bentuk stigmatisasi dan diskriminasi.

\section{Disparitas Kesehatan}

Kesehatan sebagai hak asasi dapat dikatakan belum terlaksana secara sepenuhnya. Mendapatkan derajat kesehatan yang setinggi-tingginya dimaknai bahwa tingkat kesehatan yang dapat dinikmati oleh setiap orang harus merupakan kondisi kesehatan yang tertinggi, didukung dengan sumber daya yang maksimal, dan setiap orang berhak untuk mendapatkan pelayanan, fasilitas, dan kondisi yang diperlukan untuk meningkatkan taraf kesehatan, serta mencegah, merawat, dan memulihkan kesehatan yang buruk.

Kenyataan menunjukkan masih terdapat disparitas atau kesenjangan dalam kondisi kesehatan maupun pemanfaatan pelayanan kesehatan. Padahal kesetaraan dan pemerataan dalam mendapatkan hak merupakan hal yang fundamental dari hak asasi manusia. Kesetaraan berarti pada situasi yang sama harus diperlakukan sama, sedang pemerataan mengandung makna setiap orang mendapatkan yang relatif sama dalam rangka perwujudan derajat kesehatan yang setinggi-tingginya.

Disparitas kesehatan bukan hanya terjadi di negara miskin dan negara berkembang, namun berlangsung juga di negara maju seperti di Amerika Serikat dan di Eropa Barat. Di Indonesia disparitas kesehatan terlihat pada hasil Riskesdas (Riset Kesehatan Dasar) 2018 yang diselenggarakan Kementerian Kesehatan RI. Berdasarkan aspek geografis dan sosial ekonomi terdapat disparitas dalam kondisi kesehatan, aksesibilitas terhadap pelayanan kesehatan, dan lingkungan hidup yang berpengaruh terhadap kesehatan. Penduduk perkotaan, wilayah Indonesia barat, dan kelompok sosial ekonomi menengah atas dalam aspek kesehatan menunjukkan keadaan yang lebih baik dibandingkan penduduk pedesaan, Indonesia timur, dan kelompok sosial ekonomi bawah.

Dalam hal ini, memang patut diakui bahwa tidak dapat dengan segera terwujud sepenuhnya kesehatan sebagai hak asasi manusia, terutama karena 
kondisi dan terbatasnya sumber daya yang ada. Kovenan Internasional Tentang Hak-hak Ekonomi, Sosial dan Budaya mengamanahkan bahwa perwujudan hak asasi dapat dilakukan secara progressive realisation. Perwujudan secara progressive realisation berarti dilakukan bertahap secara progresif yakni dalam rangka memenuhi hak atas kesehatan dilakukan alokasi sumber daya secara maksimal untuk memastikan bahwa kebijakan, pemberian layanan, dan derajat kesehatan selalu semakin meningkat (menunjukkan progres). Dengan demikian pemenuhan kesehatan sebagai hak asasi manusia tidak harus mutlak serta merta diimplementasikan, namun tetap harus diupayakan semakin bertambah secara berkesinambungan sesuai dengan kondisi dan kemampuan.

Berdasarkan konsepsi WHO, secara global upaya untuk pemenuhan hak atas kesehatan dijalankan melalui Universal Health Coverage (UHC) atau jaminan kesehatan semesta. Di Indonesia UHC dijalankan dalam bentuk JKN (Jaminan Kesehatan Nasional) yang dijalankan oleh BPJS Kesehatan. JKN merupakan upaya agar masyarakat memperoleh pelayanan kesehatan yang terjangkau, setara, dan merata, termasuk bagi mereka yang selama ini kesulitan untuk mendapatkannya.

\section{$\underline{\text { Stigmatisasi dan Diskriminasi }}$}

Stigmatisasi dan diskriminasi merupakan pelanggaran prinsip kesetaraan (equality) yang mendasari hak asasi manusia. Stigmatisasi merupakan pandangan negatif sebagai mereka yang dianggap bersalah atau aib. Sedangkan diskriminasi merupakan sikap dan tindakan memberikan perlakuan yang berbeda secara tidak adil. Stigmatisasi dan diskriminasi umumnya berasal dari ketidaktahuan, penyangkalan, maupun juga sikap munafik. Stigmatisasi dan diskriminasi dapat menimbulkan akibat buruk yang serius terhadap kehidupan seseorang maupun suatu kelompok. Secara sosial, stigmatisasi dan diskriminasi akan menimbulkan penolakan oleh masyarakat, perasaan tertekan dan sedih, menghambat kesempatan, dan meningkatkan kesenjangan sosial. Sedangkan di bidang kesehatan, stigmatisasi dan diskriminasi akan menjadi penghambat untuk pencegahan penyakit, mendapatkan perawatan, ketaatan berobat, serta memperburuk kondisi kesehatan. Seseorang yang mengalami stigmatisasi dan diskriminasi akan cenderung menarik diri dan menyembunyikan kondisinya hingga menghambat perawatan penyakit secara dini, bahkan dapat menularkan penyakitnya ke lingkungan sekitarnya.

Stigmatisasi dan diskriminasi yang berkaitan dengan kesehatan terutama pada penyakit HIV/AIDS, tuberkulosis paru, lepra, dan akhir-akhir ini juga pada COVID-19. Stigmatisasi dan diskriminasi terjadi karena penderita penyakit tersebut dipandang sebagai pembawa aib yang mencelakakan orang di sekitarnya. Padahal dengan bertindak wajar dan melakukan tindakan pencegahan secara baik, penyakit tersebut tidak akan menimbulkan akibat yang merugikan lingkungan sekitarnya. 
a. Stigmatisasi pada Pasien HIV

Orang dengan HIV-AIDS (ODHA) sering kali terkena stigmatisasi, hal ini terjadi karena anggapan masyarakat bahwa perilaku mereka yang menyebabkan mereka tertular HIV. Kelompok berisiko tertentu seperti pekerja seks komersial, laki-laki suka lelaki, transgender, pengguna narkoba jarum suntik dan seks bebas tanpa perlindungan. Akan tetapi, infeksi HIV juga dapat ditularkan ke bayi dari orang tua HIV, prosedur transfusi darah, prosedur medis, dan juga pasangan yang menikah dengan HIV positif (serodiscordant). Akibatnya terdapat perilaku stigmatisasi yang menyudutkan ODHA hingga dijauhkan dari pergaulan, terkena PHK dan diusir dari tempat tinggal. Selain itu, pelayanan dan profesional kesehatan seringkali mengekalkan stigma ini, yang menyebabkan luaran kesehatan pasien memburuk.

b. Stigmatisasi pada Pasien COVID-19

Pandemi COVID-19 telah memicu stigmatisasi sosial dan perilaku diskriminatif pada mereka yang tertular serta orang diduga pernah berkontak. COVID-19 merupakan penyakit baru yang menimbulkan akibat serius, dan masih banyak yang belum diketahui. Hal ini menyebabkan terjadi ketakutan dan panik, lalu cenderung mencari yang dapat dipersalahkan.Survei Fakultas Ilmu Keperawatan Universitas Indonesia dan Ikatan Perawat Kesehatan Jiwa Indonesia menunjukkan, terdapat perawat yang menangani COVID-19 kemudian diminta meninggalkan tempat tinggalnya bahkan mengalami ancaman pengusiran, orang-orang menghindari, dan masyarakat menjauhi keluarga mereka. Terdapat pula perawat yang karena statusnya sebagai perawat Covid-19 atau bertugas di rumah sakit penanganan COVID19, merasa dipermalukan oleh lingkungan sekitarnya.

Hak atas kesehatan bersifat non diskriminatif yakni setiap orang berhak mendapatkan kesehatan secara setara, tanpa perbedaan. Pemberiaan pelayanan kesehatan yang dibedakan berdasarkan latar belakang sosial ekonomi, suku, agama, ras, gender, maupun pandangan politik, hal tersebut merupakan diskriminasi.Kasus seperti menolak pemberian pelayanan kesehatan pada pasien berdasarkan latar belakang sosial ekonomi merupakan pelanggaran terhadap hak asasi di bidang kesehatan. Di Jakarta beberapa waktu lalu pernah menjadi berita yang viral mengenai bayi yang tidak diberikan perawatan di unit pediatric intensive care unit (PICU) di sebuah rumah sakit karena orangtuanya tidak mampu membayar uang muka, hingga berakhir dengan meninggalnya sang bayi. Kejadian tersebut merupakan pelanggaran terhadap hak asasi untuk mendapatkan derajat kesehatan yang setinggi-tingginya.

a. Diskriminasi pada Kaum Rentan

Diskriminasi di bidang kesehatan kerap terjadi pada kaum miskin, penyandang disabilitas, lanjut usia, narapidana, penduduk daerah terpencil, dan suku terasing. Pelaksanaan hak asasi manusia memberikan perhatian pada perlindungan terhadap kelompok rentan. Kelompok tersebut mendapatkan 
perlakuan khusus atau tindakan afirmasi atau perlindungan lebih, khususnya terkait potensi diskriminasi yang diakibatkan oleh kerentanan mereka. Tindakan afirmasi untuk melindungi hak kelompok rentan, marginal ataupun minoritas bukanlah diskriminasi, justru merupakan upaya untuk meniadakan diskriminasi.

Dalam mengatasi stigmatisasi dan diskriminasi perlu dibangun kondisi yang kondusif dalam mana penyakit dan dampaknya dapat didiskusikan dan ditangani secara terbuka, jujur, dan efektif. Agar tidak terjadi stigmatisasi dan diskriminasi di bidang kesehatan, terutama perlu dilakukan pemberian informasi yang benar dan tepat. Stigmatisasi dan diskriminasi dapat ditimbulkan karena kurangnya pengetahuan tentang penyakit, hingga perlu menyampaikan fakta yang sebenarnya. Sebaiknya terutama menyampaikan pula hal positif dan menimbulkan optimisme, seperti menekankan efektivitas pencegahan dan tindakan pengobatan. Selain itu otoritas kesehatan perlu pula menetapkan regulasi dan kebijakan untuk melindungi masyarakat agar tidak mengalami stigmatisasi dan diskriminasi.

\section{Kesimpulan}

Kesehatan merupakan hak asasi manusia untuk mendapatkan derajat kesehatan yang setinggi-tingginya, yang perwujudannya berdasarkan komponen ketersediaan, keterjangkauan, penerimaan, dan kualitas.

Permasalahan kesehatan sebagai hak asasi manusia terutama dalam bentuk disparitas kesehatan, dan masih terjadinya stigmatisasi serta diskriminasi di bidang kesehatan. Upaya mewujudkan program kesehatan yang terjangkau, setara, dan merata terutama melalui jaminan kesehatan merupakan upaya pemenuhan kesehatan sebagai hak asasi manusia.

\section{Daftar Pustaka}

Bata, Y. W., Arifin, M. A., \& Darmawansyah. (2013). Hubungan kualitas Pelayanan Kesehatan Dengan Kepuasan Pasien Penguna Akses Sosial Pada Pelayanan Rawat Inap Di RSUD Lakipadada Kabupaten Tana Toraja Tahun 2013. Jurnal Kesehatan Masyarakat, 7(256), 2-13.

Direktur RSUD Kota Makassar. SK Direktur Rumah Sakit Umum Daerah Kota Makassar Tentang Penetapan Standar Pelayanan Rumah Sakit Umum Daerah Kota Makassar. , Pub. L. No. No.112/RSUD-MKS/I/2017, 5 (2017).

Immas, H. A. P., Saryadi, \& Dewi, R. S. (2013). Pengaruh Kualitas Pelayanan terhadap Kepuasan Pasien di Rumah Sakit Islam Kota Magelang. Jurnal Ilmu Administrasi Bisnis, 2(3), 110-116.

Attoriq, S., \& Sodik, M. A. (2018). Pencegahan Dan Pengendalian Infeksi Terkait Pelayanan Kesehatan Di Lahan Praktik. 
Sodik, M. A. (2018, September). Analysis of Improved Attitude of Youth in HIV/AIDS Prevention through the Provision of Health Education with Peer Education. In The 2nd Joint International Conferences (Vol. 2, No. 2, pp. 495-502).

Sodik, M. A., \& Setyani, A. T. (2018). Effect of Smoking For Teens Against Behavior and Social Interaction.

Sodik, M. A., Suprapto, S. I., \& Pangesti, D. (2013). Faktor-Faktor Yang Berhubungan Dengan Pelaksanaan Pelayanan Prima Pegawai Di Rsui Orpeha Tulungagung. STRADA Jurnal Ilmiah Kesehatan, 2(1), 24-32.

Sari, N., Yudhana, A., Wahyuni, C., Rusmawati, A., \& Sodik, M. A. (2018). Family support As a determinant safety riding student behavior in SMKN 2 Kediri. Indian Journal of Physiotherapy and Occupational Therapy-An International Journal, 12(4), 230-234.

Sodik, M. A., Yudhana, A., \& Dwianggimawati, M. S. (2018). Nutritional status and anemia In islamic boarding school adolescent in Kediri City East Java Indonesia. Indonesian Journal of Nutritional Epidemiology and Reproductive, 1(3), 172-176.

Siyoto, S., Dwianggimawati, M. S., Sari, D. K., Mufida, R. T., \& Sodik, M. A. (2018). The Effect of Pornography Accessity to Influence Sexual Behavior. Indian Journal of Public Health Research \& Development, 9(12).

Oktoriani, E. N., Sutrisno, J., Mayasari, E., \& Sodik, M. A. (2018). Analysis of medical Record complete flexibility to complete claims of health BPJS RS Baptis Kota Batu. Journal of Global Research in Public Health, 3(1), 46-53.

Tule, A. R., Siyoto, S., Dwianggimawati, M. S., \& Sodik, M. A. (2018). The Analysis Factors Affecting Interest In Medication Of Receipt Help Aid Bpjs Participant In Balowerti Public Health Center Kediri City. Journal of Global Research in Public Health, 3(1), 68-75.

Sodik, M. A., \& Nzilibili, S. M. M. (2017). The Role Of Health Promotion And Family Support With Attitude Of Couples Childbearing Age In Following Family Planning Program In Health. Journal of Global Research in Public Health, 2(2), 82-89. 